\title{
PENGARUH PENGASAPAN TERHADAP KEAWETAN KAYU BINTANGUR (Chalophyllum sp.) DAN KAYU MEDANG (Chinnamomum sp) DARI SERANGAN RAYAP TANAH Coptotermes curvignathus Holmgren
}

The Effect Of Fumigation On The Durability Of Bintangur Wood (Chalophyllum sp) And Medang Wood (Chinnamomum sp) Against Subterranean Termite (Coptotermes curvignathus Holmgren)

Riki Andika, Farah Diba, Lolyta Sisillia

Fakultas Kehutanan Universitas Tanjungpura Jalan Imam Bonjol Pontianak 78124

e-mail: rikiandika95@gmail.com

\begin{abstract}
Medang wood (Chinnamumum sp) and Bintangur wood (Calophyllum sp) was used for timber construction even they have low quality on the durability. The efforts need to improve their durability, especially against subterranean termites, the most destructive wood organism. One methods of preservation which can improve the durability was fumigation. Fumigation can be processed with traditional methods and modern methods. The aim of the study was to improve the durability of Medang wood (Chinnamumum sp) and Bintangur wood (Calophyllum sp)with modern fumigation methods and evaluation the durability against subterranean termites Coptotermes curvignathus Holmgren. Wood sample was measured $2 \mathrm{~cm} \times 2 \mathrm{~cm} \times 1 \mathrm{~cm}$. The fumigation treatment was conducted with oven. The oven size was $1 \mathrm{~m} \times 1 \mathrm{~m} \times 50 \mathrm{~cm}$. Treatments of fumigation consits of 12 hours and 24 hours. The treatment of evaluation the durability agaisnt termites was conducted for 21 days. The wood sample was put on the bottle and 50 termites consist of 45 workers and 5 soldiers were put in the wood sample. The parameter of indicator was termite's mortality and wood weight loss. Result of the research showed that average termites mortality was reach $100 \%$ at wood sample with fumigation method for 24 hours, and $89.2 \%$ for wood sample with fumigation method for 12 hours. Meanwhile in control wood the termite's mortality only 8.6\%. The level of termites mortality with fumigation methods for 24 hours was classified very strong and for fumigation methods for 12 hours was classified as strong. The average wood weight loss was $1.21 \%-1.30 \%$. This wood weight loss was classified as very low. From the research it is concluded that fumigation method can increased the durability of wood, both on Medang wood and Bintangur wood against the subterranean termites Coptotermes curvignathus Holmgren. The optimal fumigation methods was on 12 hours, both on Medang wood and Bintangur wood.
\end{abstract}

Keywords: Calophyllum sp, Chinnamumum sp, Coptotermes curvignathus, fumigation, wood preservation

\section{PENDAHULUAN}

Indonesia memiliki luas kawasan hutan sebesar 126.094.366,71 ha dengan 8.389.601,00 ha kawasan berada di Provinsi Kalimantan Barat yang memiliki produksi kayu bulat pada tahun 2015 oleh hak pengusahaan hutan (HPH) sebesar $200.152 \mathrm{~m}^{3}$ (Badan Pusat Statistik, 2017). Kayu sebagai hasil hutan memiliki peranan penting dalam kehidupan manusia. Pemanfaatan kayu digunakan dalam berbagai keperluan terutama sebagai 
konstruksi baik konstruksi ringan maupun berat seperti bahan bangunan, pembangunan jembatan, konstruksi rumah tangga dan lain - lain.

Ada sekitar 4000 jenis kayu yang terdapat di Indonesia, Sebagian kecil kayu yang memiliki kelas keawetan alami yang tinggi, yaitu sebanyak $14,3 \%$ termasuk kelas awet I dan II. Sisanya terdiri dari jenis kayu yang kurang atau tidak awet yang dimasukkan ke dalam kelas III, IV dan V sebanyak 85,7\%.kayu - kayu yang kurang awet ini mudah dirusak oleh berbagai faktor perusak kayu terutama faktor biologis seperti jamur, serangga dan binatang laut (marine borer).

Kayu Medang dan kayu Bintangur merupakan jenis kayu yang banyak dipasarkan dengan harga yang murah. Kayu tersebut sering dimasukkan kedalam golongan rimba campuran. Pada tahun 2015 produksi kayu rimba campuran mencapai $574.545 \mathrm{~m}^{3}$. Jumlah ini menjadikan kayu rimba campuran berada diurutan kedua setelah jenis meranti sebanyak $4.169 .157 \mathrm{~m}^{3}$ (Badan Pusat Statistik, 2017). Jenis kayu rimba campuran ini menjadi pilihan bagi masyarakat sebagai pengganti kayu kelas kuat untuk kebutuhan konstruksi. Hal ini dikarenakan jenis kayu ini banyak di pasaran dan memiliki harga yang murah. Kayu Bintangur diketahui memiliki kelas awet III - IV dengan kelas kuat II-III sedangkan Kayu Medang memiliki kelas kuat II dan kelas awet III (Martawijaya dkk, 2005). Berdasarkan jenis kekuatan kayu Medang dan Bintangur cocok digunakan sebagai kayu konstruksi sebagai pengganti kayu kelas kuat I yang sulit ditemukan. Namun, dari segi keawetan kayu tersebut tergolong kurang awet sehingga dibutuhkan upaya pengawetan untuk meningkatkan keawetan kayu tersebut. Martawijaya, dkk (2005) menyatakan kayu Medang dengan kelas awet rendah sering digunakan untuk papan dan kano sedangkan Pramana (2014) menyatakan bahwa kayu Medang dianjurkan untuk pembuatan mebel dan berdasarkan morfologi serat, nilai turunan serat dan kualitas seratnya tidak cocok digunakan untuk diolah menjadi pulp dan kertas.

Upaya untuk meningkatkan keawetan kayu rimba campuran sebagai pengganti kayu kelas kuat diperlukan usaha pengawetan yang terjangkau tanpa efek samping bagi lingkungan seperti yang disebabkan oleh pengawet sintetik. Pengasapan merupakan salah satu metode pengawetan traditional yang terjangkau oleh masyarakat kelas menengah ke bawah. Asap pada pengasapan kayu terdiri atas uap dan padatan yang amat kecil yang berupa partikel-partikel yang mempunyai komposisi kimia. Oleh karena itu diperlukan penelitian lebih lanjut untuk mengetahui seberapa besar pengaruh pengasapan kayu untuk menambah keawetan kayu terutama dalam pencegahan terhadap serangan rayap.

Dalam penerapan proses pengasapan, masyarakat menggunakan ranting sebagai bahan bakar dimana ranting dari berbagai macam jenis kayu ini menghasilkan kalor 
yang tidak merata. Selain itu pengasapan secara tradisional memerlukan waktu yang relative lama ( \pm 2 pekan ) dengan pengasapan dilakukan 2 kali sehari dipagi dan sore hari selama 3 jam. Penerapan pengasapan secara tradisional juga akan memberikan hasil yang tidak rata.dimana akan terdapat satu sisi kayu yang mendapatkan hasil pengasapan sempurna sedangkan di sisi lainnya tidak mendapatkan pengasapan yang baik. Kekurangan lainnya dalam pengasapan tradisional suhu yang dihasilkan juga tidak merata dimana bagian bawah kayu akan dekat dengan sumber asap sehingga akan berpotensi merusak kayu yang akan diawetkan, sedangkan kayu yang jauh dari sumber asap akan sedikit mendapatkan efek dari pengasapan.

Oleh karena itu, penelitian ini dilakukan dengan menggunakan alat yaitu oven. Hal ini bertujuan untuk mempersingkat waktu pengasapan, memberikan suhu yang stabil selama proses pengasapan dan menggunakan bahan bakar yang homogen. Diharapkan agar proses pengawetan ini memberikan dampak yang merata disetiap sisi kayu dan meningkatkan nilai keawetan kayu.

Penelitian bertujuan untuk menguji efektivitas dari pengasapan kayu Bintangur (Calophyllum Sp.) dan kayu Medang (Chinnamumum Sp.) terhadap nilai keawetan kayu khususnya dari serangan rayap tanah Coptotermes curvignathus Holmgren serta menganalisis waktu pengasapan yang efektif dalam meningkatkan kayu Medang dan kayu Bintangur

\section{METODE PENELITIAN}

Penelitian dilakukan di Laboratorium Teknologi Kayu, Laboratorium Wood Workshop dan Laboratorium Pengolahan Kayu Fakultas Kehutanan Universitas Tanjungpura. Penelitian ini diolakukan selama \pm 2 bulan, mulai dari persiapan bahan baku, pengasapan serta pengujian terhadap rayap tanah (Coptotermes curvignathus Holmgren).

Bahan yang digunakan pada penelitian ini yaitu kayu Bintangur (Calophyllum $s p$ ) dan kayu Medang (Chinamommun $s p$ ) ukuran $2 \mathrm{~cm} \times 2 \mathrm{~cm} \times 1 \mathrm{~cm}$. Batok kelapa, pasir steril, aquades dan LPG. Alat yang digunakan satu set Oven dengan termometer $120^{\circ} \mathrm{C}$, gelas uji, wadah plastik ukuran $30 \mathrm{~cm} \times 30 \mathrm{~cm}$ dengan tutup, kawat kasa, kapas, kompor gas, besi beton, pipet tetes, kawat besi, kamera, kain hitam, amplas, oven listrik, desikator, timbangan analitik, kaliper, kalkulator dan komputer.

Penelitian menggunakan metode Syafii (2000) tentang sifat anti rayap zat ekstraktif beberapa jenis kayu daun lebar tropis yang telah dimodifikasi. Pengolahan data menggunakan menggunakan faktorial RAL mengacu pada Gasperz (1994) dengan menggunakan 2 faktor yaitu faktor jenis kayu (kayu Bintangur dan kayu Medang) dan faktor lama pengasapan (12 jam dan 24 jam) masing - masing perlakuan diulang 5 kali.

Parameter yang di teliti

1. Kondisi suhu pengasapan 
2. Perubahan berat setelah kayu diasapkan

3. Mortalitas rayap tanah

4. Penurunan berat contoh uji setelah di umpan ke rayap tanah (Coptotermes curvignathus Holmgren)

\section{Prosedur Penelitian}

Pengambilan Rayap Tanah $C$. curvignathus

Rayap tanah C. curvignathus Holmgren diambil dari Kebun Karet Desa Mekar Sari, Kabupaten Kubu Raya. Rayap diperoleh dari sisa pohon karet mati yang terserang oleh rayap, kemudian bagian tanaman karet yang terserang rayap tersebut dipotong menjadi beberapa bagian dan dimasukkan di dalam ember pemeliharaan rayap yang diberi tanah

\section{Pemeliharaan Rayap}

Pemeliharaan dilakukan dengan meletakkan ember yang berisi rayap pada sebuah bak besar yang telah berisi air dengan tujuan agar semut tidak masuk kedalam ember pemeliharaan rayap. Selanjutnya ember tersebut ditutup menggunakan kain hitam dan dikondisikan selama satu bulan atau lebih. Rayap yang digunakan dalam penelitian adalah rayap yang sehat dan aktif.

\section{Persiapan Bahan Baku}

Kayu Medang dan kayu Bintangur ukuran $4 \mathrm{~cm} \times 6 \mathrm{~cm} \times 4 \mathrm{~m}$ diambil pada bagian tengah kayu untuk dibuat contoh uji berukuran $2 \mathrm{~cm} \times 2 \mathrm{~cm} \times 1 \mathrm{~cm}$ sebanyak 15 buah untuk masing - masing kayu.

\section{Proses Pengasapan}

Metode pengasapan yang digunakan dalam proses pengasapan ini adalah metode pengasapan panas. Proses pengasapan ini menggunakan oven dengan dua ruangan. Ruangan bagian atas digunakan untuk vakum pengasapan dan bagian bawah digunakan sebagai pembakaran untuk menghasilkan asap. Bahan bakar yang digunakan untuk pengasapan ini adalah batok kelapa yang telah dikeringkan dengan menggunakan panas matahari. Sebelum dimasukkan kedalam oven, sampel kayu ditimbang untuk mengetahui berat awal kemudian dimasukkan kedalam oven dengan posisi menggantung dengan cara sampel uji diikat dengan kawat besi dan digantung pada gantungan bagian bawah yang telah disediakan didalam oven. Proses pengasapan dilakukan selama 12 jam dan 24 jam dalam keadaan kompor terus dihidupkan untuk menghasilkan asap yang konsisten dengan pengontrolan suhu maksimal $80^{\circ} \mathrm{C}$.

Setelah proses pengasapan selesai kompor gas dimatikan untuk mendinginkan suhu oven kemudian biarkan contoh uji tetap berada didalam oven dalam kondisi oven tertutup selama 30 menit. Selanjutnya pintu oven dibuka dan biarkan sampel uji berada didalam oven selama 30 menit setelah itu masukkan sampel uji ke dalam desikator selama 10 menit untuk menstabilkan kadar air kayu kemudian contoh uji ditimbang untuk mengetahui perubahan berat .

\section{Perhitungan Berat Sampel}

Perhitungan berat sampel kayu dilakukan untuk mengetahui berat sampel setelah proses pengasapan.Perhitungan 
berat disajikan melalui persamaan berikut (Akbar, 2009) :

Perhitungan berat (\%)

$$
=\frac{(\mathrm{W} 1-\mathrm{W} 2)}{\mathrm{W} 1} \times 100 \%
$$

Keterangan :

$\mathrm{W} 1=$ Berat kayu setelah diasapkan

W2 = Berat kayu sebelum diasapkan

Prosedur Pengujian Sampel Kayu Terhadap Serangan Rayap Tanah $C$ curvignathus

Setelah sampel ditimbang untuk mendapatkan perubahan berat, sampel kayu diumpankan kepada rayap tanah. Jumlah sampel kayu yang digunakan untuk masing-masing kayu terdapat 5 sampel kayu yang telah diasapkan dan 5 sampel yang tidak diasapkan.

Prosedur pengujian menggunakan metode Syafii (2000) yang telah dimodifikasi. Gelas uji dengan diameter 5 $\mathrm{cm}$ dan tinggi $6 \mathrm{~cm}$ diisi terlebih dahulu dengan pasir steril sebanyak 10 gram, dimana pasir terlebih dahulu disterilkan menggunakan autoklaf selama \pm 15 menit dengan suhu $121^{\circ} \mathrm{C}$ dan tekanan $1 \mathrm{~atm}$. Selanjutnya ditambahkan $2 \mathrm{ml}$ aquades meletakkan kasa plastik berdiameter $4 \mathrm{~cm}$ dan contoh uji di atasnya, kemudian dimasukkan 50 ekor rayap tanah yang terdiri dari 45 ekor rayap pekerja dan 5 ekor rayap prajurit yang sehat dan aktif ke dalam gelas pengujian. Setelah itu letakkan gelas uji pada bak plastik dimana pada bagian bawah diberi kapas basah untuk menjaga kelembaban udara selama pengujian kepada rayap. Selanjutnya wadah penyimpanan ditutup dan disimpan ditempat yang gelap selama 21 hari. Selama proses pengumpanan rayap tanah dikontrol selama 3 hari sekali untuk melihat jumlah rayap yang mati dan melihat kondisi kelembaban gelas uji. setelah 21 hari dilakukan perhitungan terhadap rayap yang hidup dan mati. Perhitungan mortalitas dan kehilangan berat contoh uji. Penentuan nilai mortalitas dilakukan setelah pengujian dengan menggunakan rumus (Sornnuwat, 1996):

$$
\text { Mortalitas Rayap (\%) }=\frac{\mathrm{N}_{1}-\mathrm{N}_{2}}{\mathrm{~N}_{1}} \times 100 \%
$$

Keterangan :

$N_{1}=$ Jumlah rayap awal pengumpanan (ekor)

$N_{2}=$ Jumlah rayap yang masih hidup setelah pengumpanan (ekor)

Kemudian persen kehilangan berat dihitung menggunakan rumus sebagai berikut (Sornnuwat, 1996) :

$$
A=\frac{W 1-W 2}{W 1} \times 100 \%
$$

Keterangan :

A = Kehilangan berat (\%)

$\mathrm{W} 1$ = Berat contoh uji sebelum diumpankan (gr)

$\mathrm{W} 2$ = Berat contoh uju setelah diumpankan (gr)

\section{HASIL DAN PEMBAHASAN \\ Proses pengasapan}

Proses pengasapan kayu menyebabkan sampel kayu berubah menjadi lebih gelap. Hal ini disebabkan partikel asap yang menempel pada permukaan kayu dan masuk ke dalam lumen karena partikel asap yang lebih kecil dari pori - pori kayu. Menurut Knight (2009) dalam Akbar (2009), ukuran partikel asap lebih kecil 
dari $2,5 \mu$ sedangkan pori kayu memiliki diameter 20-400 $\pi$ (Martawijaya dkk, 2005). Selain itu, perubahan warna yang terjadi juga disebabkan oleh kandungan karbonil yang terdapat di dalam asap. Adapun komponen karbonil yang paling berperan dalam perubahan warna dalam kayu adalah aldehid glikosal, dan metal glikosal sedangkan formaldehid dan hidroksiasetol memberikan peranan yang rendah. Selain itu fenol juga memberikan kontribusi pada pewarnaan kayu namun dengan intensitas yang rendah (Ruiter, 1979 dalam Yunus, 2011). Perubahan warna kayu setelah proses pengasapan dapat dilihat pada Gambar 1.

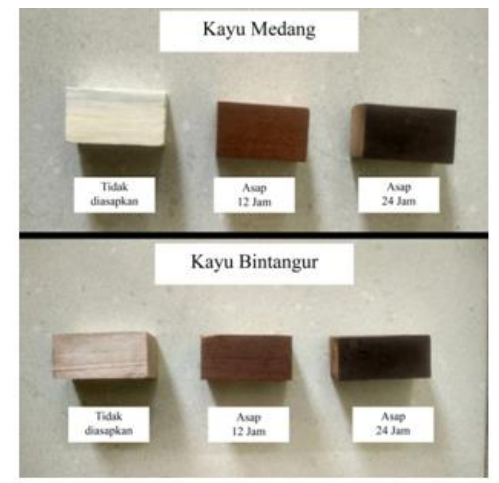

Gambar 1. Perubahan Warna Kayu Medang dan Bintangur Sebelum dan Setelah Pengasapan (Medang and Bintangur Wood Color Changes Before and After Smoked)

Pada pengukuran menggunakan Munsel Soil Color warna Kayu Medang adalah pale brown sedangkan warna Kayu Bintangur adalah pink. Pengasapan selama 12 jam menyebabkan warna kayu berubah menjadi brown dan untuk pengasapan selama 24 jam menyebabkan kayu menjadi dark brown. Hal ini sejalan dengan penelitian Hadi (2017) dimana kayu yang diasapi warnanya berubah menjadi lebih tua dengan tingkat perubahan warna tergantung dari lamanya proses pengasapan, semakin lama kayu diasapkan semakin tua warna kayu yang dihasilkan. Penus dkk (2016) dalam hasil penelitiannya menyatakan bahwa semakin lama kayu diasapkan semakin besar pula perubahan warna yang terjadi. Perubahan warna dikarenakan semakin lama proses pengasapan maka semakin banyak pula zat kimia yang dibawa oleh asap masuk ke dalam kayu.

Pengasapan yang dilakukan selama 12 jam menghabiskan 2 buah tabung gas $3 \mathrm{~kg}$ dan $14 \mathrm{~kg}$ Tempurung kelapa sedangkan untuk pengasapan selama 24 Jam membutuhkan 3 buah tabung gas $\mathrm{kg}$ dan $21 \mathrm{~kg}$ tempurung kelapa. Harga gas yang dibeli Rp. 20.000/tabung sedangkan untuk tempurung kelapa Rp.1000/kg, sehingga dana yang digunakan untuk pengasapan selama 12 jam Rp 59.000 sedangkan untuk pengasapan selama 24 jam Rp. 81.000 .

Perubahan berat setelah diasapkan

Hasil penelitian menunjukkan bahwa rata-rata perubahan berat kayu setelah 
diasapkan untuk pengasapan 12 jam berkurang $7,70 \%$ sedangkan untuk pengasapan 24 jam rata - rata berkurang $7,61 \%$. Hal ini dikarenakan sebelum proses pengasapan sampel kayu berada pada kondisi kering udara. Sehingga, pada proses pengasapan panas kadar air pada sampel kayu berkurang yang menyebabkan berkurangnya berat kayu setelah diasapkan. Hasil perubahan berat sampel kayu setelah diasapkan selama 12 jam dan 24 jam disajikan pada Gambar 2.

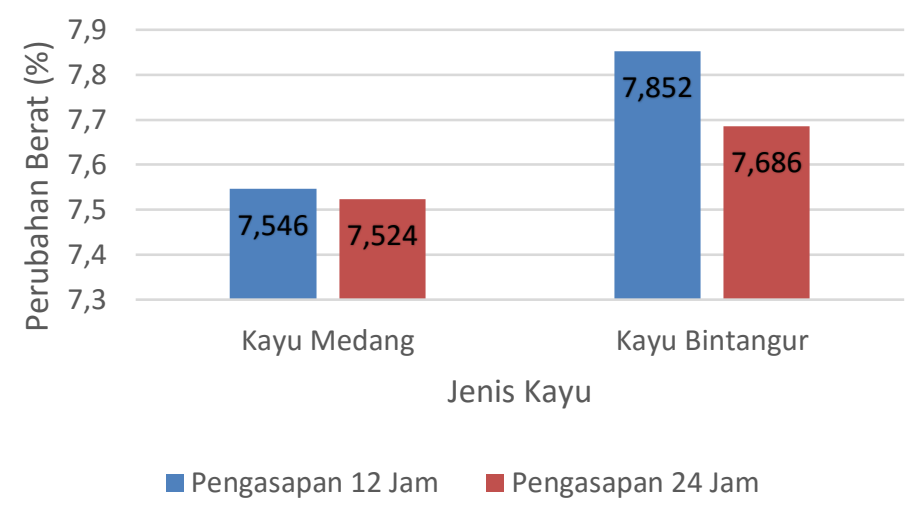

Gambar 2. Perubahan berat sampel kayu setelah diasapkan (Change in weight of wood samples after being smoked)

Perubahan berat yang terjadi saat proses pengasapan diakibatkan oleh suhu yang tinggi sehingga menyebabkan kadar air yang berada didalam kayu menjadi menguap keluar. Panas yang dihasilkan dari pembakaran kayu selama proses pengasapan menyebabkan terjadinya proses pengeringan kayu. Pengeringan kayu menyebabkan terjadinya penurunan kadar air kayu. Disamping akibat panas, proses pengeringan kayu terjadi karena adanya proses penarikan air dari sel-sel dan pori-pori kayu akibat penyerapan berbagai senyawa kimia yang berasal dari asap hasil pembakaran kayu. Asap hasil pembakaran kayu terdiri atas karbondioksida, aldehid, alkohol, asam organik dan lainnya. Hadiwiyoto dkk (2000), menyatakan proses pengasapan menghasilkan penurunan kadar air yang lebih baik dibandingkan dengan pemberian asap cair kepada produk yang diberi perlakuan. Asap hasil pembakaran adalah campuran dari gas, cairan dan padatan yang tediri atas karbondioksida dalam bentuk gas, air dalam bentuk gas dan butiran-butiran, alkohol dan aldehid dalam bentuk cairan dan gas yang mudah menguap serta zat-zat padat yang tdak terbakar dan ikut terbawa arus asap. Royani dkk (2015) merancang alat pengasapan yang semi modern dengan bahan bakar tempurung kelapa. Alat dapat mengasapkan ikan tongkol (Euthynussaffinis) dalam waktu 3 jam dengan pemakaian bahan bakar sebesar 60\%. Ikan yang dihasilkan memiliki kadar air rendah dan rasa yang disukai. Faktor yang mendukung keberhasilan teknik pengasapan 
kayu dalam mengawetkan kayu adalah jenis kayu yang digunakan sebagai bahan bakar, waktu pengasapan dan alat yang digunakan dalam pengasapan

Mortalitas Rayap Tanah C. curvignathus
Hasil penelitian menunjukkan bahwa semakin lama proses pengasapan semakin tinggi nilai mortalitas rayap tanah. Nilai rerata mortalitas rayap tanah dapat dilihat pada Gambar 3.

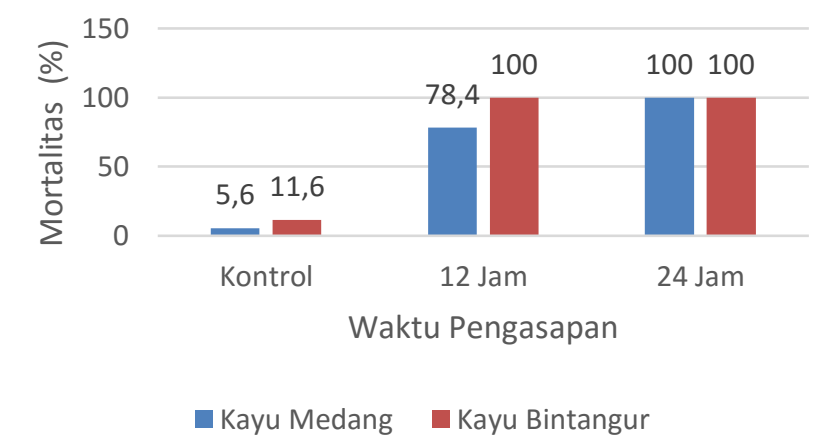

Gambar 3. Nilai Rerata Mortalitas Rayap Tanah Coptotermes curvignathus (The Average value of subteranean termite mortality Coptotermes curvignathus)

Mortalitas rayap tanah pada Gambar 3, menunjukkan bahwa nilai mortalitas rayap pada pengasapan 24 jam menunjukkan nilai rerata mortalitas $100 \%$ tergolong tingkat aktifitas anti rayap sangat kuat, untuk mortalitas rayap tanah pengasapan 12 jam rata - rata mencapai $89,2 \%$ tergolong aktivitas anti rayap sangat kuat, dan tanpa pengasapan (kontrol) dengan rerata mortalitas $8,6 \%$ tergolong aktivitas anti rayap tidak aktif.

Salah satu indikator yang digunakan untuk melihat daya racun dari proses pengasapan adalah dengan melihat persentase mortalitas rayap. Mortalitas adalah persentase dari jumlah rayap yang mati diakhir pengujian. Tingkat mortalitas rayap dapat dilihat dengan pengujian aktivitas pengasapan terhadap rayap tanah C. curvignathus, dimana mortalitas dapat ditentukan dari persentase jumlah rayap yang mati diakhir pengujian selama 21 hari. Hasil penelitian menunjukkan nilai mortalitas bervariasi dari $74 \%$ sampai $100 \%$, sementara pada kayu yang tidak diasapkan nilai mortalitas rayap paling tinggi sebesar $10 \%$. Hasil penelitian menunjukkan tingkat aktivitas anti rayap pada pengasapan 12 jam menunjukkan nilai rata-rata mortalitas $75 \% \leq \mathrm{m}<95 \%$ dan termasuk tingkat aktivitas anti rayap kuat, sedangkan pada pengasapan 24 jam nilai mortalitas $m \geq 95 \%$ tergolong tingkat aktivitas anti rayap sangat kuat. Sedangkan pada kayu tanpa pengasapan dengan nilai rata-rata mortalitas $8,6 \%$ tergolong tingkat aktivitas anti rayap tidak aktif.

Tingginya kematian rayap tanah pada kayu yang diasapi sebagian besar terjadi karena kelaparan dan sebagian kecil karena keracunan. Hal tersebut dapat dilihat dari angka kehilangan berat, 
diduga rayap lebih memilih mati atau memakan sesama rayap daripada memakan kayu yang diasapi dan hanya sebagian kecil rayap yang memakan kayu yang diasapi.

Mortalitas rayap pada pengasapan diduga karena adanya pengaruh komponen kimia yang melekat pada sampel kayu dan bersifat toksik terhadap rayap tanah $C$. curvignathus. Menurut Jayanudin dan Suhendi (2012) asap cair dari tempurung kelapa mengandung senyawa 2-propanon, acetat acid methyl ester, methanol, 2buthanon, 2-propanon, 1-hydroxy 2butanon, asam asetat ethilyc acid, furancarboxandehyde, phenol 2-methoxy, Benzene 1,4 dimethoxy, dan phenol. Kandungan fenol menurut Kesumaningrum dkk (2011) merupakan senyawa organik berbahaya yang memiliki kadar racun yang tinggi. Hasil penelitian ini juga didukung oleh penelitian Akbar (2009) dalam percobaannya pada kayu mindi, pulai dan sengon dengan pengasapan selama 3 pekan dimana mortalitas sampel kayu yang diasapkan mencapai $100 \%$.

Kemungkinan lain yang terjadi terhadap mortalitas rayap tanah $\mathrm{C}$. curvignathus adalah rayap akan memilih makanan yang sesuai dan memenuhi syarat untuk dimakan, dan apabila tidak ditemukan makanan yang sesuai maka rayap akan berpuasa, rayap tersebut perlahan akan mulai melemah dan mati. Dalam kondisi ini sifat kanibalisme dan necropaghy pada rayap akan berlaku, dimana rayap yang lebih sehat akan memakan rayap yang lemah atau memakan bangkai sesamanya yang mati karena kondisi kurang makanan. Rayap sehat yang memakan rayap yang lemah atau mati tersebut akan terkena efek dari senyawa toksik yang terdapat pada rayap yang telah dimakannya, dengan demikian maka rayap sehat tersebut akan mati.

Hutabarat dkk, (2015) menyatakan bahwa pada tahap awal rayap akan menyesuaikan diri dengan lingkungan hidup yang baru, dan selanjutnya akan mencicipi makanan dengan cara menggigit bagian permukaan kayu, apabila bagian tersebut tidak sesuai rayap akan beralih kebagian permukaan kayu lainnya sampai akhirnya menemukan bagian yang memenuhi syarat sebagai makanan dan apabila makanan itu sesuai rayap akan meneruskan makan. Tetapi jika tidak ditemukan bagian yang memenuhi syarat maka rayap tersebut memilih meninggalkan makanan dan berpuasa. Dalam kondisi ini rayap akan lemah dan berangsur-angsur sakit atau mati. Tambunan dan Nandika (1989) dalam Sucipto (2008) menyatakan bahwa mortalitas rayap dipengaruhi oleh sifat kanibalisme pada kasta rayap pekerja dengan cara membunuh serta memakan rayap yang tidak produktif (karena sudah tua, sakit, atau malas) baik pada kasta reproduktif, kasta prajurit, maupun pada kasta pekerja itu sendiri. Tarumingkeng (2001) dalam Sucipto (2008) menyatakan bahwa sifat kanibalisme berfungsi untuk mengefesiensikan energi pada koloni rayap tanah. 
Kehilangan Berat Sampel Kayu

Hasil penelitian menunjukkan bahwa semakin lama proses pengasapan, maka kehilangan berat Sampel kayu semakin rendah. Nilai rerata kehilangan berat sampel kayu dapat dilihat pada Gambar 4.

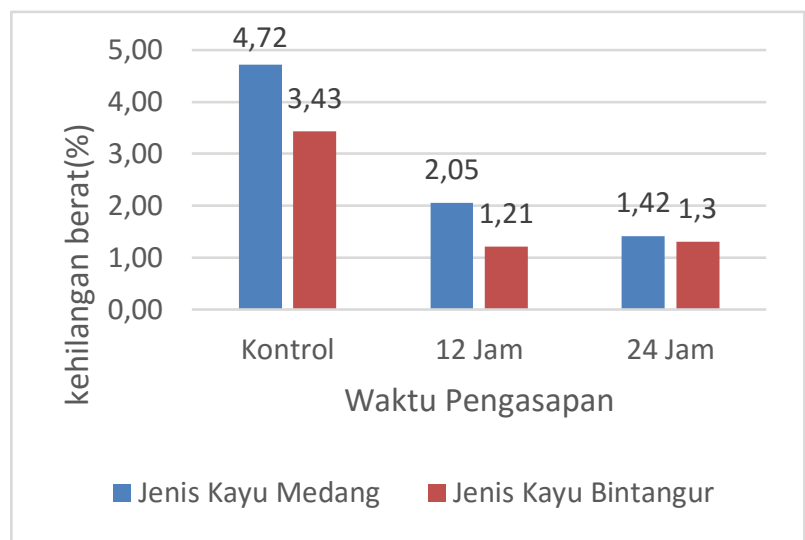

Gambar 4. Nilai rerata kehilangan berat sampel kayu setelah diumpankan pada rayap tanh Coptotermes curvignathus ( The average value of weight lose of the wood sample after being fed to sebteranean termites Coptotermes curvignathus)

Berdasarkan hasil penelitian persentase kehilangan berat sampel kayu cendrung menurun dengan meningkatnya waktu pengasapan.. Hal ini didukung dengan penelitian Efendi, (2015) yang menyatakan bahwa semakin lama waktu pengasapan pada kayu, semakin kecil tingkat kehilangan berat sampel. Serta pengasapan yang dilakukan pada kayu glulam terbukti meningkatkan resistensi terhadap serangan rayap tanah $C$. curvignathus. Diduga pengurangan berat yang kecil pada kayu yang diasapkan disebabkan aroma yang keluar dari kayu yang telah diasapkan sehingga rayap enggan untuk memakan serat sampel kayu yang telah diasapkan. Asap memiliki polycyclic aromatic hydrocarbons dalam jumlah banyak yang komposisinya terdiri dari phenol, aldehid, keton, asam organik, alkohol, eter, hidrokarbondan berbagai senyawa heterocyclic (Stolyhwo dan Skorski, 2005 dalam Akbar 2009). Jenis kayu Bintangur yang diasapkan 12 jam dan 24 jam merupakan penghambat daya makan rayap paling tinggi sehingga pengurangan berat yang ditimbulkan pada sampel kayu Bintangur yang diasapkan 12 jam merupakan yang paling rendah yaitu $1,21 \%$ selanjutnya diikuti pengasapan sampel kayu Bintangur selama 24 jam sebesar $1,30 \%$. Kayu yang tidak diasapkan jenis kayu Bintangur memiliki nilai pengurangan berat yang berbeda sangat nyata bila dibandingkan dengan kayu Medang dimana kayu Bintangur memiliki nilai mengurangan berat sebesar $3,43 \%$ sedangkan kayu Medang sebesar 4,72\%. Hal ini disebabkan karena pada kayu Bintangur memiliki BJ yang lebih tinggi dibandingkan dengan Medang, pada penelitian yang dilakukan oleh Arif dkk 
(2009) dalam Nandika (2015) pada pengujian preferensi makan rayap $C$. curvignathus menghasilkan kayu palapi (Heritiera sp.) yang memiliki $\mathrm{Bj}$ yang lebih tinggi mengalami tingkat konsumsi yang lebih rendah dibandingkan kayu nyatoh (Palaqium. $S p$ ) dan meranti putih (Shorea sp.). Rata - rata pengasapan sampel kayu 24 jam menunjukkan kehilangan berat yang lebih sedikit dibandingkan rata - rata sampel kayu yang diasapkan selama 12 jam. Hal ini dikarenakan banyaknya zat kimia yang terkandung dalam asap yang menempel pada permukaan kayu pada pengasapan 24 jam dibandingkan dengan pengasapan selama 12 jam yang dibuktikan dengan perbedaan warna yang terjadi setelah sampel kayu diasapkan. Hal ini sejalan dengan penelitian Efendi (2015) dimana semakin lama pengasapan menyebabkan semakin sedikit kehilangan berat yang terjadi pada sampel kayu dan mempengaruhi perilaku makan rayap terhadap kayu.

Perbedaan hasil rata - rata kehilangan berat sampel kayu setelah dilakukan pengumpanan pada rayap tanah $C$. curvignathus pada waktu pengasapan 12 jam dan 24 jam menunjukkan hasil yang tidak berbeda nyata sesuai dengan Efendi (2015), dimana pengasapan glulam selama 15 hari dan 30 hari menunjukkan hasil yang tidak berbeda nyata namun berpengaruh sangat nyata terhadap glulam yang tidak diasapkan. Kondisi sampel kayu setelah setelah pengumpanan disajikan pada Gambar 5.

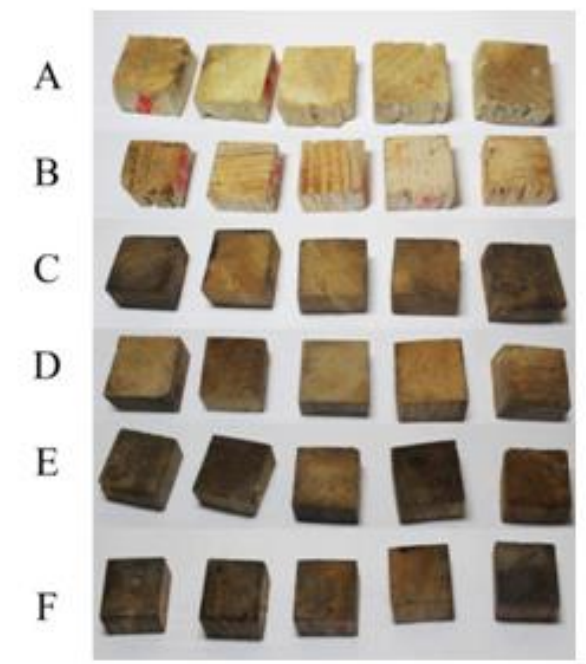

Gambar 5. Sampel kayu setelah pengumpanan terhadap rayap tanah Coptotermes curvignathus (Wood samples after feeding on the sebteranean termites Coptotermes curvignathus)

$\mathrm{A}=$ Medang tanpa pengasapan

$\mathrm{B}=$ Bintangur tanpa pengasapan

$\mathrm{C}=$ Medang pengasapan 12 jam
$\mathrm{D}=$ Bintangur pengasapan 12 jam

$\mathrm{E}=$ Medang pengasapan $24 \mathrm{jam}$

$\mathrm{F}=$ Bintangur pengasapan 24 jam 
Semakin lama kayu diasapkan semakin banyak zat kimia yang terkandung dalam asap menempel pada permukaan kayu dibuktikan dengan tingginya daya toksik yang dapat dilihat pada tingginya mortalitas rayap tanah $C$. curvignathus dan kecilnya kehilangan berat sampel kayu. Sampel kayu yang tidak diasapkan kehilangan berat sangat besar, hal ini dikarenakan tidak ada senyawa toksik pada sampel kayu sehingga masih banyak rayap yang hidup sampai akhir pengujian.

Perlakuan pengasapan dapat meningkatkan kelas awet Kayu Bintangur dan Kayu Medang. Hal ini dibuktikan kelas awet Kayu Bintangur dan Kayu Medang diketahui berada pada kelas awet III setelah diberikan perlakuan pengasapan menjadi kelas awet I. Perlakuan pengasapan efektif ditunjukkan pada pengasapan selama 12 jam pada kedua jenis kayu yang menunjukkan nilai mortalitas rayap tanah C. curvignathus $89,2 \%$ dengan kehilangan berat rata - rata $1,63 \%$. Waktu pengasapan yang singkat ini efektif untuk pemanfaatan kayu untuk pembangunan

\section{Kesimpulan}

Berdasarkan hasil penelitian yang telah dilakukan dapat ditarik kesimpulan bahwa

1. Proses pengasapan selama 12 jam dan 24 jam terbukti efektif untuk meningkatkan ketahanan kayu Bintangur dan kayu Medang dari serangan rayap tanah Coptothermes curvignathus.
2. Tingkat aktivitas anti rayap pengasapan kayu selama 24 jam menunjukkan nilai rata-rata mortalitas $m \geq 95 \%$ tergolong tingkat aktivitas anti rayap sangat kuat, pada pengasapan 12 jam mortalitas sebesar $75 \% \leq \mathrm{m}<95 \%$ dan termasuk tingkat aktivitas anti rayap kuat.

3. Kayu yang tidak diasapkan memiliki nilai rata-rata mortalitas $<10 \%$ dan tergolong tingkat aktivitas anti rayap tidak aktif.

4. Pengasapan 12 jam terbukti memberikan hasil yang efektif dengan nilai mortalitas rayap tanah sebesar 89,2\% dengan kehilangan berat sampel kayu sebesar 1,63\% dengan tingkat aktivitas anti rayap tergolong sanat kuat baik pada kayu Medang dan kayu Bintangur.

5. Perlakuan pengasapan dapat meningkatkan kelas awet kayu Bintangur dan kayu Medang. Hal ini dibuktikan kelas awet kayu Bintangur dan kayu Medang diketahui berada pada kelas awet III setelah diberikan perlakuan pengasapan menjadi kelas awet I (SNI 2006).

\section{Saran}

Perlu dilakukan pengujian rayap tanah di lapangan dan uji sifat fisik dan mekanik kayu yang telah diasapkan.

\section{DAFTAR PUSTAKA}

Akbar, Taufik Opik. 2009. Ketahanan Kayu yang Diawetkan dengan Pengasapan dari Serangan Rayap tanah Coptotermes curvignathus Holmgren dan Rayap Kayu Kering Cryptotermes cynocephalus Light. Institut Pertanian Bogor. Bogor. 
Badan Pusat Statistik. 2017. Luas kawasan Hutan \& Kawasan Konservasi Perairan Indonesia Menurut Provinsi Berdasarkan SK Menteri kehutanan. BPS. Jakarta

Badan Pusat Statistik. 2017. Produksi Kayu Bulat Oleh Hak Pengusahaan Hutan Menurut Jenis Kayu, 20142015. BPS. Jakarta

Efendi, Mulyani. 2015. Peningkatan Keawetan glulam. Dari Tiga jenis Kayu Cepat Tumbuh dengan Pengasapan. Institut Pertanian bogor. Bogor

Gasperz, V. 1994. Metode Perancangan Percobaan. Armico. Bandung.

Hadi, Yusuf Sudo. 2017. Teknologi Kayu Asap. IPB Press. Bandung

Hadiwiyoto, S., Darmaji, P., dan Purwasari S.R. 2000. Comparison of Thermal Smoking and the Use of Liquid Smoke in Fish Processing: Review Content Benzopiren, Phenol and Organoleptic Properties of Smoked Fish. Journal Agritech 20:14-19

Hutabarat NK, Oemry S, Pinem MI. 2015. Uji Efektivitas Termisida Nabati Terhadap Mortalitas Rayap (Coptotermes curvignathus Holmgren) (Isoptera : Rhinotermitidae) Di Laboratorium. Jurnal Agroekoteknologi 3 (1). 103111

Kesumaningrum, Juwita. Prasetya, Nor Basid Adiwibawa. Suseno, Ahmad. 2011. Adsorbsi Fenol dengan $\mathrm{TiO}_{2} /$ zeolit artificial Berbahan Dasar Sekam Padi dan Limbah Kertas. Jurnal Kimia Sains dan Aplikasi 14 (1) : $26-31$
Jayanudin. Suhendi, Endang. 2012. Identifikasi Komponen Kimia Asap Cair Tempurung Kelapa dari Wilayah Anyer Banten.Jurnal Agroekotek 4 (1) 39 - 46

Martawijaya, Abdurahim. Kartasujana, Iding. Kadir, Kosasi. Prawira, Among Soewanda. 2005. Atlas Kayu Indonesia Jilid 1.Badan Penelitian dan Pengembangan Kehutanan. Bogor

Nandika, D. Rismayadi, Yudi. Diba, Farah. 2015. Rayap Biologi dan Pengendalian. Muhammadiyah University Press. Surakarta

Penus, Diba, Farah. Sisillia, Lolyta. 2016. Pengaruh Lama Pengasapan Terhadap Sifat Fisik dan Mekanik Kayu Laban Vitex pubescens Vahl dan Akasia Acacia mangium Wild. Jurnal Hutan Lestari 5 (3) : 732 740

Pramana, handoko Ignatius. 2014 Pemanfaatan Kayu Medang Berdasarkan Morfologi Serat, Nilai Turunan Dimensi Serat, Sudut Mikrofibril dan Turunannya. Institut Pertanian Bogor. Bogor

Royani D.S., Marasabessy I., Santoso J., Nurimala M. 2015. Rekayasa Alat Pengasapan Ikan Tipe Kabinet (Model Oven). Jurnal Aplikasi Teknologi Pangan 4 (2):74-78.

Sornnuwat, Y. 1996. Resistance of Commercial Timber and Fast Growing Timber of Thailand for Building Construction to Coptotermes Gestroi Wasmann. Proc. The 1996 Annual Meeting of The International Research Group on 
JURNAL TENGKAWANG (2019)

Vol. 9 (1) : 28 - 41

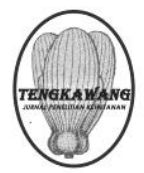

Wood Preservation, Stockholm Sweden

Standar Nasional Indonesia. 2006. Standar Nasional Indonesia (SNI). SNI 01.7202-2006. Uji Ketahanan Kayu dan Produk Kayu Terhadap Organisme Perusak Kayu Dewan Standar Nasional. Jakarta

Sucipto. 2008. Persistensi Nematoda Entomopatogen Heterorhabditis (All strain) Isolat Lokal Madura Terhadap Pengendalian Rayap Tanah Macrotermes sp. (Isoptera : Termitidae) Di Lapang. Jurnal Embryo 5 (2) :193-208

Syafii W. 2000. Sifat Anti Rayap Zat Ekstraktif Beberapa Jenis Kayu Daun Lebar Tropis. Bulletin Kehutanan No. 42. Fakultas Kehutanan UGM. Yogyakarta. 